\title{
Penerapan Metode Analytical Hierarchy Process Dan Technique for Order Preference by Similarity to Ideal Solution Sebagai Pendukung Keputusan Dalam Menentukan Kenaikan Jabatan Bagi Guru
}

\author{
Sri Siswanti ${ }^{1 *}$; Fatwa Lingga Wrehatnala ${ }^{2)}$; Andriani Kusumaningrum ${ }^{3)}$ \\ ${ }^{1 *)}$ Program Studi Teknik Informatika, STMIK Sinar Nusantara Surakarta \\ 2) Program Studi Sistem Informasi, STMIK Sinar Nusantara Surakarta \\ 3) Program Studi Komputerisasi Akuntansi, STMIK Sinar Nusantara Surakarta \\ ${ }^{1)}$ syswanty@sinus.ac.id ; ${ }^{2}$ fatwalinggaw95@gmail.com; ${ }^{3)}$ andrianikkw@sinus.ac.id;
}

\begin{abstract}
Thesis report entitled "Application of AHP and TOPSIS Method as Decision Support System in Determining Position Promotion for Teachers of Vocational High School in Surakarta" is based on research by the author carried out located in Jl. Dr. Wahidin 33 Surakarta on 28 September 2018 6 Agustus 2019. The purpose of this paper is to make Application of AHP and TOPSIS Method as Decision Support System in Determining Position Promotion for Teachers of Vocational High School in Surakarta to integrate the selection of recipients in order to avoid manipulation of the data in the provision of accurate decisions. Data collection was conducted by the author uses descriptive method that includes field studies and literature. Field studies were conducted are interviews with the Vocational High School related problems. While the literature study is useful to get a theoretical basis in the form of expert opinion on matters which is the object of research. It is also used to assist writers in the execution of a research report by the author. The result of the manufacturing Application of AHP and TOPSIS Method as Decision Support System in Determining Position Promotion for Teachers of Vocational High School Surakarta consists of input data including teachers data, criteria data, the data classifications, and data input analysis. The results of position promotions for teachers on Vocational High School Surakarta was given to best alternative with score of 88.12, while on using with AHP and TOPSIS method was given to best alternative with score of 0.7238 .
\end{abstract}

Keywords: Decision Support System, AHP, TOPSIS, Determining, Teacher, Position Promotion

\section{PENDAHULUAN}

Pengambilan keputusan penentuan kenaikkan jabatan saat ini masih menggunakan cara manual, yang dilakukan secara musyawarah bersama dengan guru ketika akan melakukan promosi jabatan. Jangka waktu dalam kenaikan jabatan bagi guru adalah satu tahun sekali tepat setelah kenaikan kelas. Penilaian terhadap guru dilakukan secara terpantau kemudian disampaikan pada waktu musyawarah diadakan. Salah satu kendala dalam mengambil keputusan yaitu terkadang dalam menentukan kenaikan jabatan atau promosi bagi guru bisa menjadi subyektif. Selain itu dalam pemilihan membutuhkan waktu yang relatif lama karena guru diseleksi yang belum menggunakan perhitungan.

Berdasarkan permasalahan diatas, maka perlu suatu sistem yang digunakan dalam menunjang pengambilan keputusan dalam menentukan kenaikan jabatan bagi guru. Metode yang digunakan dalam penentuan kenaikan jabatan ini menggunakan metode Analytical Hierarchy Process (AHP) dan Technique for Order Preference by Similarity to Ideal Solution (TOPSIS). Penerapan metode ini digunakan untuk menghindari penilaian secara subyektif, sehingga dapat meminimalisir waktu dan adil dalam kenaikan jabatan. Maka untuk mengembangkan sistem kenaikan jabatan atau promosi tersebut harus membandingkan kriteria-kriteria dari guru.

Penelitian ini bertujuan untuk merancang dan membuat aplikasi Sistem Pendukung Keputusan dengan AHP dan TOPSIS untuk menentukan kenaikan jabatan guru. Kombinasi metode ini dipilih dengan alasan metode AHP memliki kelebihan berdasar pada matriks perbandingan pasangan dan melakukan analisis konsistensi. Sedangkan metode TOPSIS dapat menyelesaikan pengambilan keputusan secara praktis, karena konsepnya sederhana 
dan mudah dipahami, komputasinya efisien, serta memiliki kemampuan mengukur kinerja relatif dari alternatif-alternatif keputusan. (Chamid \& Murti, 2017).

Penentuan bobot dan kriteria menggunakan metode AHP, sedang untuk menentukan peringkat alternatif menggunakan metode TOPSIS. Bobot kriteria yang dihasilkan dari metode AHP merupakan nilai input yang digunakan oleh metode TOPSIS untuk mengurutkan alternatif yang dipilih.(Servanda \& Kusrini, 2018).

Penelitian Andriyani \& Hafiz (2018), menggunakan metode AHP dan TOPSIS dalam memberikan rekomendasi kepada siswa yang berprestasi sesuai dengan yang diharapkan. Hasil penelitian membuktikan bahwa aplikasi sistem penunjang keputusan ini mampu membantu madrasah dalam proses seleksi pemilihan siswa berprestasi (Andriyani \& Hafiz, 2018). SPK dengan model AHP dan TOPSIS mudah dalam melakukan perubahan bobot pada setiap sesi penilaian (Nanik Hidayati dkk., 2016).

\section{TINJAUAN PUSTAKA}

\subsection{Penelitian Terkait}

Penelitian Herman Firdaus et al., (2016) tentang sistem pendukung keputusan untuk merekomendasikan karyawan terbaik pada PT South Pacific Viscose berdasarkan kriteria yang telah ditetapkan yaitu: pengetahuan, kemampuan, sikap, absensi, dan kerjasama. Penelitian ini menggunakan metode $A H P$ dan TOPSIS. Hasil pengujian yang dilakukan yaitu dengan memasukkan sample data karyawan sebanyak 300 orang kemudian berhasil diolah dalam waktu 0,9531 detik sehingga terbukti sistem ini melakukan perhitungan lebih cepat dibanding sebelumnya. Sistem ini dapat memberikan rekomendasi karyawan terbaik berdasarkan ranking, dari 300 karyawan terdapat 3 karyawan dengan ranking terbesar yaitu: Hilman Bakhtiar 0.9549, Basuki Cahyo Setyo 0.9126 dan Dimas Haryandi 0.8276

Penelitian Chamid \& Murti, (2017), penggunaan metode AHP dan TOPSIS dapat memberikan peringkat bakal calon staf kurikulum sekolah berdasarkan 9 kriteria yang digunakan. Berdasarkan pertanyaan SPK dengan model AHP dan TOPSIS ini mudah dalam melakukan perubahan bobot pada setiap sesi penilaian. Hal ini didasarkan pada pertanyaan 4 dengan hasil 80 persen sangat setuju dan 40 persen setuju.

Penelitian (Ramayanti \& Ulum, 2017) menggunakan metode Analythical Hierarcy Process (AHP) untuk pemilihan kriterianya dan Tehnique For Order Performance By Similiar To Ideal Solution untuk mengevaluasi alternative supplier. Hasil perhitungan AHP didapat bobot masing-masing kriteria, untuk kualitas sebesar 0.0644 , harga 0.056, waktu pengiriman 0.158, kuantitas 0.053, respon terhadap klaim sebesar 0.093. Pemilihan Vendor dengan menggunakan metode TOPSIS dengan menggunakan acuan kriteria yang dihitung dengan AHP. Hasil pemilihan yang menduduki peringkat pertama adalah supplier S2 sebagai supplier prioritas dengan nilai Preferensi yaitu 0.322, karena supplier S2 memiliki keunggulan pada kriteria kualitas, harga, kuantitas.

\subsection{Sistem Pendukung Keputusan}

Sistem pendukung Keputusan diartikan sebagai suatu sistem yang dirancang dan digunakan untuk menunjang manajemen di dalam pengambilan keputusan. (Latif et al., 2018)

Turban (Latif et al., 2018) mendefinisikan SPK sebagai suatu informasi berbasis komputer yang menghasilkan berbagai alternative keputusan untuk membantu manajemen dalam menangani berbagai permasalahan yang terstruktur maupun tidak terstruktur dengan menggunakan data dan model. 


\subsection{Analytical Hierarchy Process (AHP)}

AHP merupakan suatu model pendukung keputusan yang dikembangkan oleh Thomas L. Saaty. AHP merupakan metoda pengambilan keputusan yang melibatkan sejumlah kriteria dan alternatif yang dipilih berdasarkan pertimbangan semua kriteria terkait (Saaty, 2004). Kriteria memiliki derajat kepentingan yang berbeda-beda, demikian pula halnya alternatif memiliki preferensi yang berbeda menurut masing-masing kriteria yang ada.

Model pendukung keputusan ini akan menguraikan masalah multi faktor atau multi kriteria yang kompleks menjadi suatu hirarki, hirarki didefinisikan sebagai suatu representasi dari sebuah permasalahan yang kompleks dalam suatu struktur multilevel dimana level pertama adalah tujuan, yang diikuti level faktor, kriteria, sub kriteria, dan seterusnya ke bawah hingga level terakhir dari alternatif. Dengan hirarki, suatu masalah yang kompleks dapat diuraikan ke dalam kelompok-kelompoknya yang kemudian diatur menjadi suatu bentuk hirarki sehingga permasalahan akan tampak lebih terstruktur dan sistematis. (Arbelia \& Paryanta, 2014)

Langkah penyelesaian dengan metode $A H P$ (Nofriansyah \& Defit, 2017) adalah sebagai berikut

1. Mendefinisikan kriteria-kriteria yang akan dijadikan tolah ukur penyelesaian masalah dan menentukan tingkat kepentingan setiap kriteria.

2. Berdasarkan tabel nilai kepentingan, dihitung nilai matriks perbandingan.

3. Menentukan nilai bobot $\left(\mathrm{W}_{\mathrm{i}}\right)$

$$
\begin{aligned}
& W_{i}=\frac{1}{n} \sum_{j} a_{i j} \\
& \mathrm{i}, \mathrm{j}=1,2,3 \ldots . \mathrm{n}
\end{aligned}
$$

4. Menentukan nilai Consistency index

$$
C I=\frac{(\lambda \max -n)}{(n-1}
$$

Dimana $\mathrm{n}=$ banyaknya elemen.

$\lambda \max =$ Eigenvalue Maksimum

$\mathrm{CI}=$ Indeks Konsistensi

5. Menentukan nilai Consistency Ratio

$$
C R=\frac{C I}{I R}
$$

Dimana

$$
\begin{aligned}
& \mathrm{CR}=\text { Consistency Ratio } \\
& \mathrm{CI}=\text { Consistency Index } \\
& \mathrm{IR}=\text { Index Random }
\end{aligned}
$$

Nilai consistency index seperti pada Tabel 1.

Tabel 1. Nilai Consistency Index

\begin{tabular}{|l|c|c|}
\hline No & Jumlah n kriteria & RIn \\
\hline 1. & 2 & 0 \\
\hline 2. & 3 & 0.58 \\
\hline 3. & 4 & 0.90 \\
\hline 4. & 5 & 1.12 \\
\hline 5. & 6 & 1.24 \\
\hline 6. & 7 & 1.32 \\
\hline 7. & 8 & 1.41 \\
\hline 8. & 9 & 1.45 \\
\hline 9. & 10 & 1.49 \\
\hline
\end{tabular}




\subsection{Technique for Others Reference by Similarity to Ideal Solution (TOPSIS)}

TOPSIS merupakan salah satu metode pengambilan keputusan multikriteria yang pertama kali diperkenalkan oleh Yoon dan Hwang. Prinsip dari metode ini adalah alternatif yang terpilih harus mempunyai jarak terdekat dari solusi ideal positif dan terjauh dari solusi ideal negatif dari sudut pandang geometris dengan menggunakan jarak Euclidean untuk menentukan kedekatan relatif dari suatu alternatif dengan solusi optimal. (Sari et al., 2018)

Konsep metode TOPSIS bahwa alternative terpilih tidak memiliki jarak terpendek dari solusi ideal positif tetapi juga memiliki jarak terpanjang dari solusi ideal negative. (Riandari et al., 2017).

Penyelesaian dengan metode TOPSIS (Nofriansyah \& Defit, 2017)

1. Menentukan kriteria yang akan dijadikan tolak ukur penyelesaian masalah.

2. Setiap alternatif di normalisasi dan membuat matriks ternomalisasi terbobot. Guna menghitung nilai ternormalisasi rij dengan rumus :

$$
\mathfrak{r}_{i j}=\frac{x_{i j}}{\sqrt{\sum_{i=1}^{m} x^{2} i j}}
$$

Untuk $\mathrm{i}=1,2,3, \ldots, \mathrm{m}$ dan $\mathrm{j}=1,2,3, \ldots, \mathrm{n}$

3. Membuat matriks keputusan yang ternormalisasi terbobot.

$$
\mathrm{Y}_{\mathrm{ij}}=\mathrm{W}_{\mathrm{ij}} \cdot \mathrm{r}_{\mathrm{ij}}
$$

Dengan $\mathrm{i}=1,2,3, \ldots, \mathrm{m}$ dan $\mathrm{j}=1,2,3, \ldots, \mathrm{n}$

4. Menentukan matriks solusi ideal positif dan matriks solusi ideal negatif.

$$
\begin{aligned}
& \mathrm{A}^{+}=\left(y_{1}^{+}, y_{2}^{+} \ldots, y_{n}^{+}\right) ; \\
& \mathrm{B}^{-}=\left(y_{1}^{-}, y_{2}^{-} \ldots, y_{n}^{-}\right) ; \\
& \text {Dengan : }
\end{aligned}
$$

$$
\begin{gathered}
y_{1}^{+}=\left\{\begin{array}{c}
\max y_{i j} ; j i k a j \text { adalah atribut keuntungan } \\
\min y_{i j} ; j i k a \text { adalah atribut biaya }
\end{array}\right. \\
y_{1}^{-}=\left\{\begin{array}{c}
\max y_{i j} ; j i k a j \text { adalah atribut } \text { keuntungan } \\
\min y_{i j} ; j \text { ika } j \text { adalah atribut biaya }
\end{array}\right. \\
\text { Nilai } \mathrm{j}=1,2, \ldots, \mathrm{n} .
\end{gathered}
$$

5. Menentukan jarak antara nilai setiap alternatif dengan matriks solusi ideal positif dan matriks solusi ideal negatif.

$$
\begin{aligned}
& D_{i}^{+}=\sqrt{\sum_{j=1}^{n}\left(v_{i j}-v_{j}^{+}\right)^{2}}, \text { dengan }=1,2,3, \ldots, \mathrm{n} \\
& D_{i}^{-}=\sqrt{\sum_{j=1}^{n}\left(v_{i j}-v_{j}^{-}\right)^{2}}, \text { dengan }=1,2,3, \ldots, \mathrm{n}
\end{aligned}
$$

6. Menentukan nilai preferensi untuk setiap alternative dirumuskan sebagai berikut :

$$
V_{i}=\frac{D_{i}^{-}}{D_{i}^{-}+D_{i}^{+}}
$$

dengan $0 \mid<V_{i}<1$ dan $i=1,2,3, \ldots, m$. Nilai $V_{i}$ yang lebih besar menunjukkan bahwa alternatif $A_{i}$ lebih dipilih.

Penerapan metode TOPSIS dalam aplikasi sistem pendukung keputusan pemilihan kepala departemen yaitu dengan melakukan perangkingan dari setiap alternatif pada setiap kriteria, selanjutnya dicari nilai terbesar dari setiap alternatif untuk menentukan kepala departemen. Hasil penelitian menunjukkan bahwa yang memilik nilai tertinggi adalah Sandy Nazar yang layak menjadi kepala departemen. (Riandari et al., 2017). 


\section{METODE PENELITIAN}

\subsection{Pengumpulan Data}

Pengumpulan data dilakukan dengan wawancara kepada wakil kepala sekolah, observasi di bagian tata usaha dan studi leteratur berupa buku atau jurnal, catatan, bukti yang telah ada, atau arsip.

\subsection{Desain Sistem}

Dalam desain sistem menggunakan teknik sebagai berikut :

1) Context Diagram

Gambaran secara global aliran data pembuatan sistem informasi yang akan di buat.

2) Hierarchy Input Process Output (HIPO)

HIPO merupakan urutan pengolahan aplikasi dari top level turun ke level 0 hingga diuraikan ke level paling akhir yaitu level 1.

3) Data Alir Diagram (DAD)

DAD dibuat dengan mengacu pada Context Diagram dan HIPO. DAD yang dibuat adalah DAD level 0 yaitu gambaran alir data dari Input, Proses dan Output.

\subsection{Implementasi}

Implementasi sistem yang telah dibuat berdasarkan perancangan program yang mengacu pada alur data. Untuk menerapkan sistem, diperlukan adanya penjelasan mengenai penggunaan sistem ini kepada user (pengguna). Penentuan alternatif kenaikan jabatan bagi guru menggunakan AHP dan TOPSIS. Pembangunan aplikasi menggunakan bahasa pemrograman PHP, sedang databasenya menggunakan MySQL.

\subsection{Pengujian}

Pada penelitian ini menggunakan pengujian validitas yaitu membandingkan hasil perhitungan manual dan perhitungan dengan menggunakan aplikasi.

\section{HASIL DAN PEMBAHASAN}

\subsection{Context Diagram}

Context Diagram seperti pada Gambar 1, menunjukkan rancang bangun sistem pendukung keputusan kenaikan jabatan guru yang terdiri dari 3 external entity, yaitu: Guru, Petugas (Wakasek), dan Kepala Sekolah.

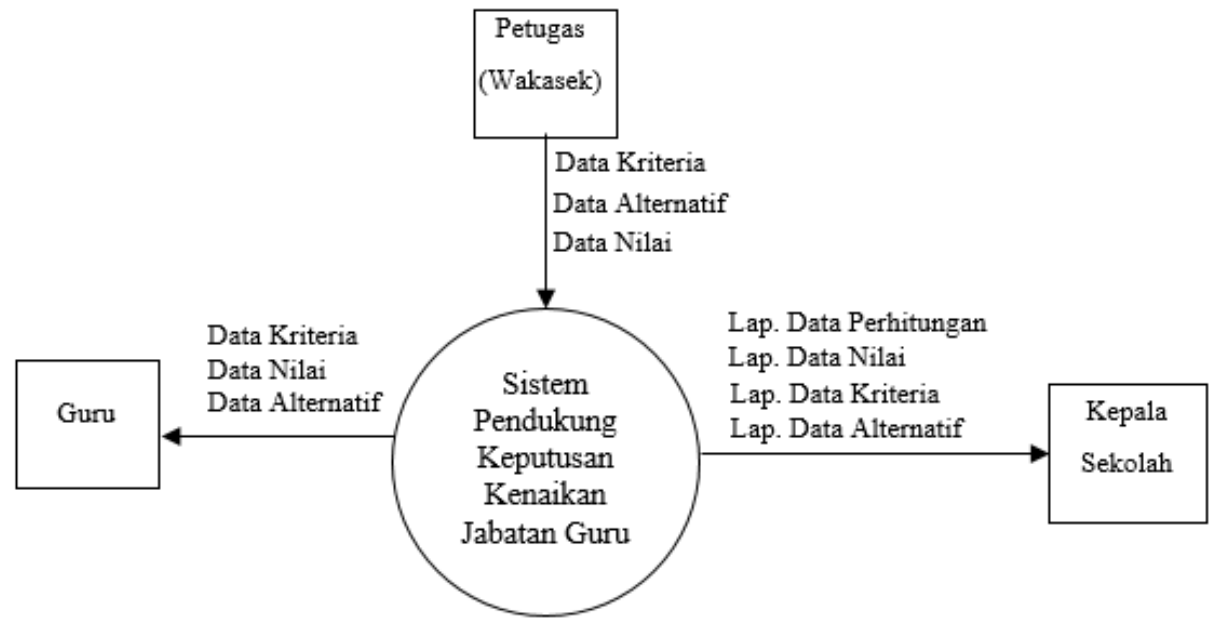

Gambar 1. Diagram Konteks 


\subsection{Hierarchy Input Proses Output (HIPO)}

HIPO pada sistem pendukung keputusan kenaikan jabatan guru ini terdiri dari 3 level yaitu top level yang berisi sistem informasi secara keseluruhan, Level 0 yang terdiri dari 3 proses yaitu input, proses dan output, sedang level 1 berisi turunan dari proses 1 .

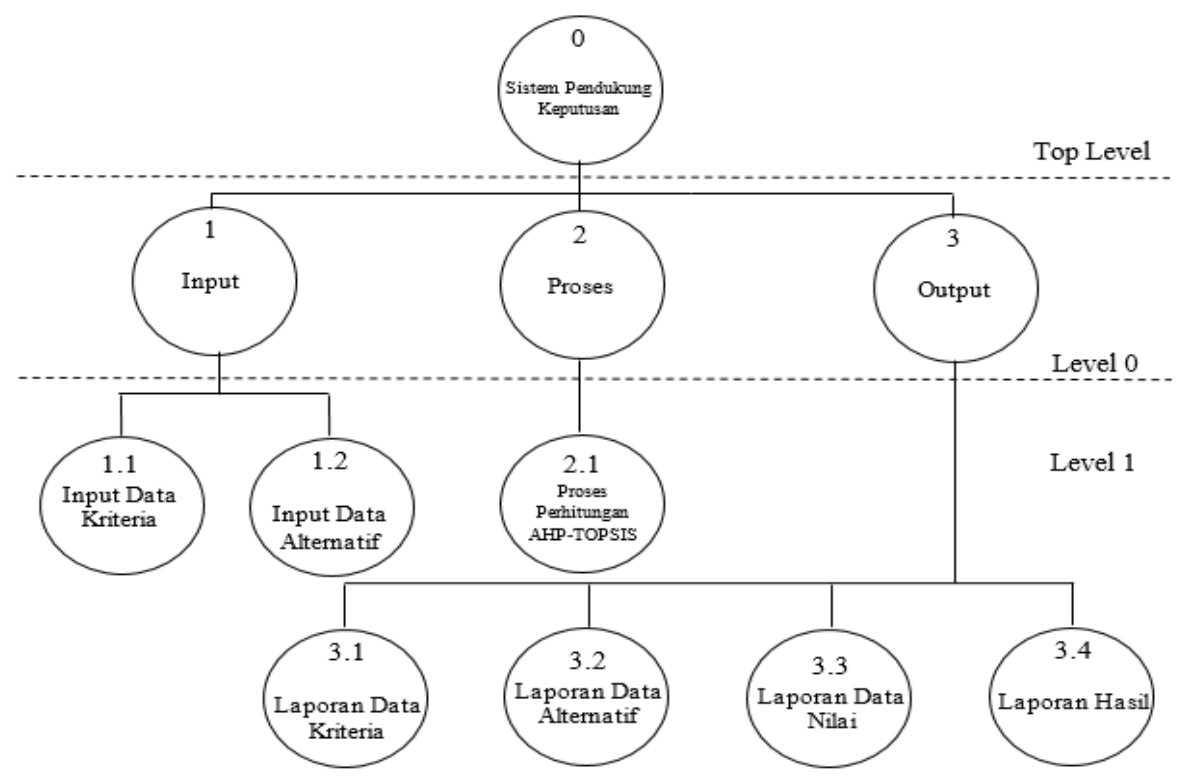

Gambar 2. HIPO

\subsection{Diagram Alir Data}

Penjabaran diagram kontek dan HIPO adalah Diagram Alir Data (DAD). DAD Level 0 seperti pada Gambar 3 terdiri dari 3 proses yaitu input, proses dan output. Kesatuan luar yang terlibat dalam system ini adalah Wakasek, kepala sekolah dan Guru yang akan di nilai.

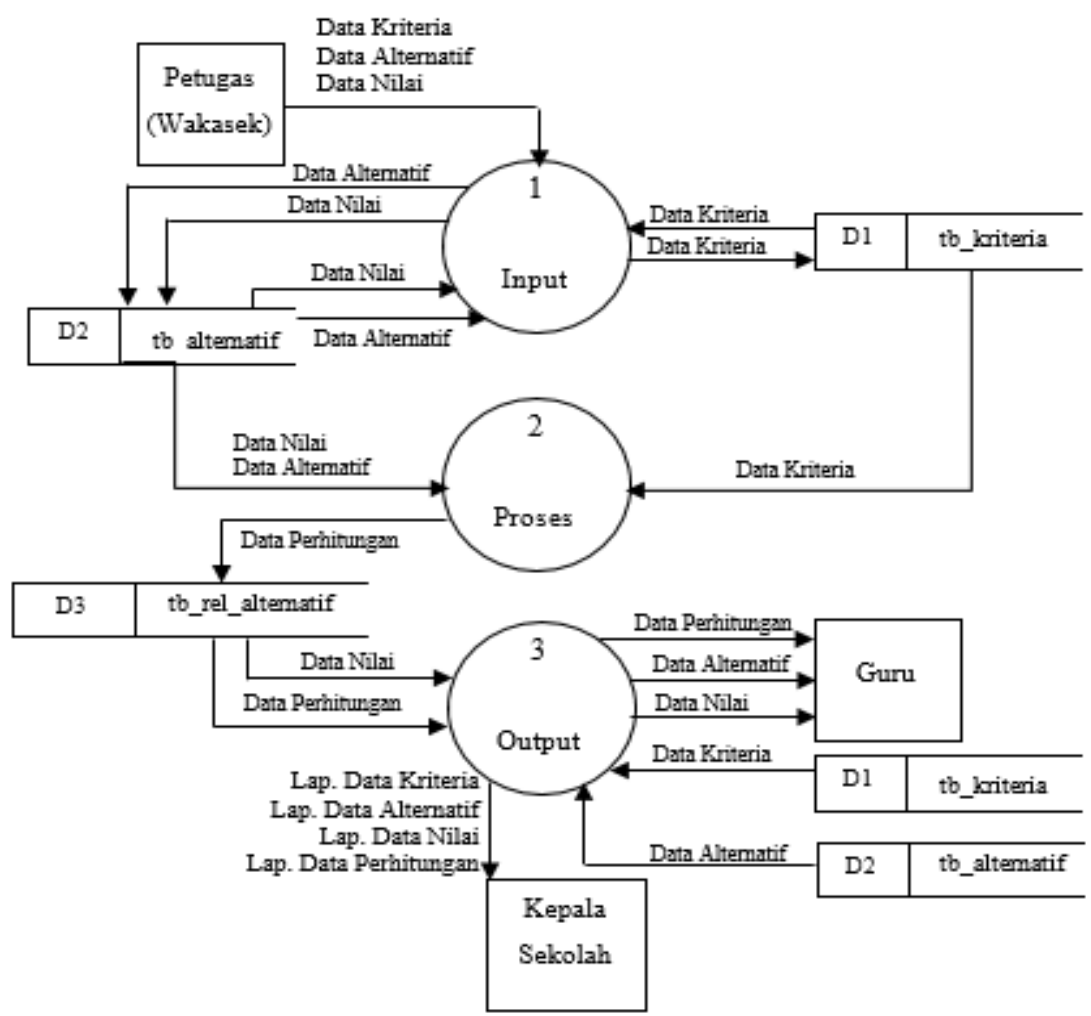

Gambar 3. DAD Level 0 


\subsection{Perhitungan AHP dan TOPSIS}

Guna menghitung nilai kriteria dan bobot nilai kriteria dalam menentukan kenaikan jabatan guru menggunakan metode AHP. Adapun kriteria yang digunakan adalah :
$\mathrm{C} 1=$ Absensi Guru
$\mathrm{C} 2=$ Sikap Guru
C3 = Feedback Siswa ke Guru
C4 = Prestasi Non-Akademik Guru
C5 $=$ Pendidikan Guru

Pada Tabel 2 merupakan hasil nilai konversi berdasarkan data nilai alternatif di sekolah, sedang matriks nilai perbandinagn kriteria seperti pada Tabel 3. Matriks ini di dapat dari perbandingan antara satu kriteria dengan kriteria yang lain.

Tabel 2. Hasil Nilai Konversi

\begin{tabular}{|l|c|c|c|c|c|c|c|c|c|c|c|c|}
\hline \multirow{2}{*}{\multicolumn{1}{c|}{ Kriteria }} & \multicolumn{10}{|c|}{ Alternatif } \\
\cline { 2 - 16 } & $\mathbf{A 1}$ & $\mathbf{A 2}$ & $\mathbf{A 3}$ & $\mathbf{A 4}$ & $\mathbf{A 5}$ & $\mathbf{A 6}$ & $\mathbf{A 7}$ & $\mathbf{A 8}$ & $\mathbf{A 9}$ & $\mathbf{A 1 0}$ & $\mathbf{A 1 1}$ & $\mathbf{A 1 2}$ \\
\hline Absensi & 10 & 9 & 10 & 8 & 9 & 10 & 10 & 8 & 10 & 9 & 7 & 10 \\
\hline Sikap & 7 & 7 & 10 & 7 & 7 & 7 & 10 & 7 & 7 & 10 & 7 & 10 \\
\hline Feedback Siswa & 7 & 7 & 8 & 9 & 9 & 9 & 7 & 10 & 8 & 7 & 7 & 8 \\
\hline Prestasi Non Akademik & 4 & 4 & 4 & 6 & 2 & 4 & 2 & 6 & 4 & 2 & 8 & 2 \\
\hline Pendidikan & 4 & 4 & 4 & 4 & 4 & 4 & 4 & 7 & 4 & 4 & 7 & 4 \\
\hline
\end{tabular}

Tabel 3. Matriks Nilai Perbandingan Kriteria Awal

\begin{tabular}{|l|c|c|c|c|c|}
\hline Kriteria & C1 & C2 & C3 & C4 & C5 \\
\hline C1 & 1 & 3 & 5 & 7 & 9 \\
\hline C2 & 0,333 & 1 & 3 & 5 & 7 \\
\hline C3 & 0,2 & 0,333 & 1 & 3 & 5 \\
\hline C4 & 0,143 & 0,2 & 0,333 & 1 & 3 \\
\hline C5 & 0,111 & 0,143 & 0,2 & 0,333 & 1 \\
\hline Jumlah & 1,787 & 4,676 & 9,533 & 16,333 & 25,000 \\
\hline
\end{tabular}

Berdasarkan Tabel 3, membuat matriks perbandingan berpasangan dengan menggunakan persamaan (1), hasil matriks perbandingan berpasangan seperti pada Tabel 4. Nilai bobot di dapat dari rata-rata pada matriks perbandingan.

Tabel 4. Matriks perbandingan berpasangan

\begin{tabular}{|l|l|l|l|l|l|r|}
\hline Kriteria & C1 & C2 & C3 & C4 & C5 & $\begin{array}{l}\text { Nilai } \\
\text { Bobot }\end{array}$ \\
\hline C1 & 0,560 & 0,642 & 0,524 & 0,429 & 0,36 & 0,50 \\
\hline C2 & 0,186 & 0,214 & 0,315 & 0,306 & 0,28 & 0,26 \\
\hline C3 & 0,112 & 0,071 & 0,105 & 0,184 & 0,20 & 0,13 \\
\hline C4 & 0,080 & 0,043 & 0,035 & 0,061 & 0,12 & 0,07 \\
\hline C5 & 0,062 & 0,031 & 0,021 & 0,020 & 0,04 & 0,03 \\
\hline
\end{tabular}

Vektor jumlah bobot seperti pada Tabel 5, yaitu dengan mengalikan parameter dengan matriks pertama pada kolom pertama dan seterusnya sampai data ke 5 . 
Tabel 5. Vektor Jumlah Bobot

\begin{tabular}{|l|r|r|r|r|r|l|}
\hline Kriteria & \multicolumn{1}{|c|}{ C1 } & \multicolumn{1}{c|}{ C2 } & \multicolumn{1}{|c|}{ C3 } & \multicolumn{1}{c|}{ C4 } & \multicolumn{1}{c|}{ C5 } & Hasil \\
\hline C1 & 0,50284902 & 0,78061731 & 0,6717101 & 0,47453142 & 0,31331681 & $\mathbf{2 , 7 4 3 0 2 5}$ \\
\hline C2 & 0,16744873 & 0,26020577 & 0,4030261 & 0,33895101 & 0,24369086 & $\mathbf{1 , 4 1 3 3 2 2}$ \\
\hline C3 & 0,1005698 & 0,08664852 & 0,134342 & 0,20337061 & 0,1740649 & $\mathbf{0 , 6 9 8 9 9 6}$ \\
\hline C4 & 0,07190741 & 0,05204115 & 0,0447359 & 0,0677902 & 0,10443894 & $\mathbf{0 , 3 4 0 9 1 4}$ \\
\hline C5 & 0,05581624 & 0,03720942 & 0,0268684 & 0,02257414 & 0,03481298 & $\mathbf{0 , 1 7 7 2 8 1}$ \\
\hline
\end{tabular}

Rata-rata konsistensi seperti pada Tabel 6 adalah dengan mencari rata-rata dari rasio konsistensi, dimana rasio konsistensi di dapat dari vektor jumlah bobot di bagi dengan nilai bobot.

Tabel 6. Vektor konsistensi

\begin{tabular}{|c|c|c|}
\hline Kriteria & Rasio Konsistensi & Hasil \\
\hline C1 & $2,74302469 / 0,50284902$ & 5,455 \\
\hline C2 & $1,41332244 / 0,26020577$ & 5,432 \\
\hline C3 & $0,69899586 / 0,13434202$ & 5,203 \\
\hline C4 & $0,3409136 / 0,0677902$ & 5,029 \\
\hline C5 & $0,17728119 / 0,03481298$ & 5,092 \\
\hline & Jumlah & $\mathbf{2 6 , 2 1 1}$ \\
\hline & Rata-rata konsistensi $(\lambda)$ & $\mathbf{5 , 2 4 2}$ \\
\hline
\end{tabular}

Perhitungan Consisteny Index (CI) menggunakan persamaan 2.

$$
\begin{aligned}
\mathrm{CI} & =(5,242-5) /(5-1) \\
& =0,242194 / 4 \\
& =\mathbf{0 , 0 6 0 5 5}
\end{aligned}
$$

Penghitungan Consistency Ratio (CR) menggunakan persamaan (3), sedang consistency index menggunakan RIn 1.12 (merujuk pada Tabel 1) karena menggunakan 5 data.

$$
\begin{aligned}
\mathrm{CR} & =0,06055 / 1.12 \\
& =\mathbf{0 , 0 5 4 0}(\mathbf{C R}<\mathbf{0 . 1}, \text { nilai } \text { ACCEPTABLE })
\end{aligned}
$$

\begin{tabular}{|c|c|c|c|c|c|c|c|c|c|c|c|c|c|c|}
\hline \multirow[b]{2}{*}{ Kriteria } & \multicolumn{14}{|c|}{ Alternatif } \\
\hline & A1 & A2 & A3 & A4 & A5 & A6 & A7 & A8 & A9 & A10 & A11 & A12 & Jumlah & $\begin{array}{l}\text { Hasil } \\
\text { Akar }\end{array}$ \\
\hline Absensi & 10 & 9 & 10 & 8 & 9 & 10 & 10 & 8 & 10 & 9 & 7 & 10 & 1020 & 31,9374 \\
\hline Sikap & 7 & 7 & 10 & 7 & 7 & 7 & 10 & 7 & 7 & 10 & 7 & 10 & 792 & 28,1425 \\
\hline $\begin{array}{l}\text { Feedback } \\
\text { Siswa }\end{array}$ & 7 & 7 & 8 & 9 & 9 & 9 & 7 & 10 & 8 & 7 & 7 & 8 & 780 & 27,9285 \\
\hline $\begin{array}{l}\text { Prestasi Non } \\
\text { Akademik }\end{array}$ & 4 & 4 & 4 & 6 & 2 & 4 & 2 & 6 & 4 & 2 & 8 & 2 & 232 & 15,2315 \\
\hline Pendidikan & 4 & 4 & 4 & 4 & 4 & 4 & 4 & 7 & 4 & 4 & 7 & 4 & 258 & 16,0624 \\
\hline
\end{tabular}

Perhitungan TOPSIS menggunakan data alternatif sesuai dengan Tabel 2, kemudian dicari jumlah hasil kuadarat tiap elemen kriteria data alternatif seperti pada Tabel 7.

Tabel 7. Jumlah Hasil Kuadarat Tiap Elemen Kriteria Data Alternatif 
Nilai ternormalisasi rij dihitung dengan menggunakan persamaan (4), sehingga normalisasi keputusan matrik R seperti pada Tabel 8.

Tabel 8. Normalisasi Keputusan Matriks R (4)

\begin{tabular}{|l|c|c|c|c|c|c|c|c|c|c|c|c|}
\hline \multirow{2}{*}{ Kriteria } & \multicolumn{10}{|c|}{ Alternatif } \\
\cline { 2 - 14 } & $\mathbf{A 1}$ & $\mathbf{A 2}$ & $\mathbf{A 3}$ & $\mathbf{A 4}$ & $\mathbf{A 5}$ & $\mathbf{A 6}$ & $\mathbf{A 7}$ & $\mathbf{A 8}$ & $\mathbf{A 9}$ & $\mathbf{A 1 0}$ & $\mathbf{A 1 1}$ & $\mathbf{A 1 2}$ \\
\hline Absensi & 0,313 & 0,282 & 0,313 & 0,250 & 0,282 & 0,313 & 0,313 & 0,250 & 0,313 & 0,282 & 0,219 & 0,313 \\
\hline Sikap & 0,249 & 0,249 & 0,355 & 0,249 & 0,249 & 0,249 & 0,355 & 0,249 & 0,249 & 0,355 & 0,249 & 0,355 \\
\hline Feedback Siswa & 0,251 & 0,251 & 0,286 & 0,322 & 0,322 & 0,322 & 0,251 & 0,358 & 0,286 & 0,251 & 0,251 & 0,286 \\
\hline $\begin{array}{l}\text { Prestasi Non } \\
\text { Akademik }\end{array}$ & 0,263 & 0,263 & 0,263 & 0,394 & 0,131 & 0,263 & 0,131 & 0,394 & 0,263 & 0,131 & 0,525 & 0,131 \\
\hline Pendidikan & 0,249 & 0,249 & 0,249 & 0,249 & 0,249 & 0,249 & 0,249 & 0,436 & 0,249 & 0,249 & 0,436 & 0,249 \\
\hline
\end{tabular}

Perhitungan nilai ternormalisasi rij menggunakan persamaan (5), sehingga matriks keputusan normalisasi pembobotan seperti pada Tabel 9.

Tabel 9. Matriks Normalisasi Pembobotan

\begin{tabular}{|l|c|c|c|c|c|c|c|c|c|c|c|c|}
\hline \multirow{2}{*}{ Kriteria } & \multicolumn{10}{|c|}{ Alternatif } \\
\cline { 2 - 13 } & $\mathbf{A 1}$ & $\mathbf{A 2}$ & $\mathbf{A 3}$ & $\mathbf{A 4}$ & $\mathbf{A 5}$ & $\mathbf{A 6}$ & $\mathbf{A 7}$ & $\mathbf{A 8}$ & $\mathbf{A 9}$ & $\mathbf{A 1 0}$ & $\mathbf{A 1 1}$ & $\mathbf{A 1 2}$ \\
\hline C1 & 0,157 & 0,142 & 0,157 & 0,126 & 0,142 & 0,157 & 0,157 & 0,126 & 0,157 & 0,142 & 0,11 & 0,157 \\
\hline C2 & 0,065 & 0,065 & 0,092 & 0,065 & 0,065 & 0,065 & 0,092 & 0,065 & 0,065 & 0,092 & 0,065 & 0,092 \\
\hline C3 & 0,034 & 0,034 & 0,038 & 0,043 & 0,043 & 0,043 & 0,034 & 0,138 & 0,038 & 0,034 & 0,034 & 0,038 \\
\hline C4 & 0,018 & 0,018 & 0,018 & 0,027 & 0,009 & 0,018 & 0,009 & 0,018 & 0,018 & 0,009 & 0,036 & 0,009 \\
\hline C5 & 0,009 & 0,009 & 0,009 & 0,009 & 0,009 & 0,009 & 0,009 & 0,436 & 0,009 & 0,009 & 0,015 & 0,009 \\
\hline
\end{tabular}

Penentuan matriks solusi ideal positif dan negatif menggunakan formula (8) dan (9). Sehingga di dapat hasil seperti pada Tabel 10, sedang hasil separation measure untuk positif dan negatif seperti pada Tabel 11.

Tabel 10. Solusi Ideal Positif dan Negatif

\begin{tabular}{|c|c|c|}
\hline Kriteria & $\begin{array}{c}\text { Solusi Ideal } \\
\text { Positif }\end{array}$ & $\begin{array}{c}\text { Solusi Ideal } \\
\text { Negatif }\end{array}$ \\
\hline C1 & 0,1574 & 0,1102 \\
\hline C2 & 0,0925 & 0,0647 \\
\hline C3 & 0,0481 & 0,0337 \\
\hline C4 & 0,0356 & 0,0089 \\
\hline C5 & 0,0152 & 0,0087 \\
\hline
\end{tabular}

Tabel 11. Separation Measure Positif dan Negatif

\begin{tabular}{|c|c|c|}
\hline Alternative & SiMax & SiMin \\
\hline A1 & 0,0366 & 0,04806 \\
\hline A2 & 0,0398 & 0,03272 \\
\hline A3 & 0,0213 & 0,0557 \\
\hline A4 & 0,0437 & 0,02564 \\
\hline A5 & 0,0424 & 0,03292 \\
\hline A6 & 0,0339 & 0,04902 \\
\hline A7 & 0,031 & 0,05478 \\
\hline A8 & 0,0429 & 0,02855 \\
\hline A9 & 0,035 & 0,0483 \\
\hline A10 & 0,0348 & 0,04196 \\
\hline A11 & 0,0566 & 0,02748 \\
\hline A12 & 0,0291 & 0,05499 \\
\hline
\end{tabular}


Perangkingan dilakukan dengan cara menentukan nilai preferensi untuk setiap alternative, langkah ini menggunakan formula (10).

$$
\begin{aligned}
& \mathrm{A} 1=\frac{0.04806}{0.04806+0.03656}=0.5679, \text { Rank } 6 \\
& \mathrm{~A} 2=\frac{0.03272}{0.03272+0.03981}=0.4511, \text { Rank } 8 \\
& \mathrm{~A} 3=\frac{0.05570}{0.05570+0.02125}=0.7238, \text { Rank } 1 \\
& \mathrm{~A} 4=\frac{0.02564}{0.02564+0.04365}=0.3700, \text { Rank } 11 \\
& \mathrm{~A} 5=\frac{0.03292}{0.03292+0.04238}=0.4372, \text { Rank } 9 \\
& \mathrm{~A} 6=\frac{0.04902}{0.04902+0.03394}=0.5909, \text { Rank } 4 \\
& \mathrm{~A} 7=\frac{0.05478}{0.05478+0.03104}=0.6383, \text { Rank } 3 \\
& \mathrm{~A} 8=\frac{0.02855}{0.02855+0.04290}=0.3996, \text { Rank } 10 \\
& \mathrm{~A} 9=\frac{0.04830}{0.04830+0.03495}=0.5802, \text { Rank } 5 \\
& \mathrm{~A} 10=\frac{0.04196}{0.04196+0.03480}=0.5466, \text { Rank } 7 \\
& \mathrm{~A} 11=\frac{0.02748}{0.02748+0.05664}=0.3267, \text { Rank } 12 \\
& \mathrm{~A} 12=\frac{0.05499}{0.05499+0.02912}=0.6538, \text { Rank } 2
\end{aligned}
$$

\subsection{Implementasi}

Pada menu utama terdiri dari 4 pilihan yaitu kriteria, alternatif, Perhitungan dan password. Menu kriteria terdiri dari input data kriteria dan bobot kriteria. Menu alternatif digunakan untuk mengisi data alternatif dan untuk input nilai bobot masing-masing nilai alternatif dari masing-masing kriteria. Menu perhitungan yang berisi data nilai, normalisasi, pembobotan, nilai preferensi, dan hasil perangkingan yang telah diproses. Menu Password yang digunakan untuk mengubah password lama menjadi password yang baru, menu Logout untuk keluar ke halaman Login, dan menu.

Proses perhitungan seperti pada Gambar 4 pengukuran konsistensi kriteria dengan AHP yang meliputi: matriks perbandingan kriteria, matriks bobot prioritas kriteria, matriks konsistensi kriteria, consistency index, ratio index, dan consistency ratio. Selanjutnya terdapat perhitungan TOPSIS sesuai dengan tahapannya yaitu tahap hasil analisa sampai perangkingan. dan terdapat tombol cetak untuk melihat preview (pratinjau) cetakan sebelum hasil akan dicetak. Halaman ini dirujuk pada Gambar 5. 


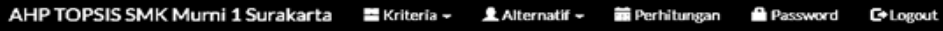

\section{Perhitungan}

\begin{tabular}{l|}
\hline Mengukur Konsistensi Kriterla (AHP) \\
\hline Matriks Perbandingan Kriteria \\
Matriks Bobot Prioritas Kriteria \\
Matriks Konsistensi Kriteria \\
Consistency Index 0.061 \\
Ratio Indec: 1.12 \\
Consistency Ratio: 0.054 (Konsisten) \\
\end{tabular}

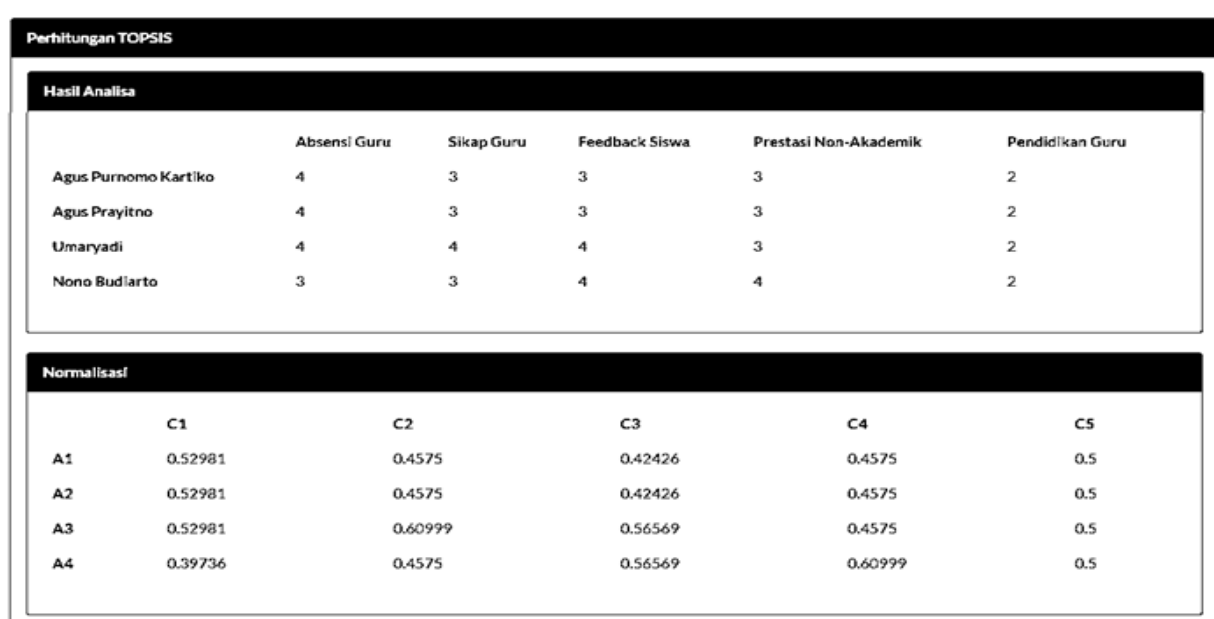

\begin{tabular}{|c|c|c|c|c|c|}
\hline & $c_{1}$ & $\mathrm{C2}$ & $\mathrm{C3}$ & $C_{4}$ & cs \\
\hline A1 & 0.2664 & 0.11905 & 0.057 & 0.03101 & 0.01741 \\
\hline A2 & 0.2664 & 0.11905 & 0.057 & 0.03101 & 0.01741 \\
\hline$A 3$ & 0.2664 & 0.15874 & 0.076 & 0.03101 & 0.01741 \\
\hline${ }^{A 4}$ & 0.1998 & 0.11905 & 0.076 & 0.04134 & 0.01741 \\
\hline
\end{tabular}

\section{Matriks Solusi Ideal}

\begin{tabular}{|llllll|}
\hline & $\mathrm{C1}$ & $\mathrm{C2}$ & $\mathrm{C3}$ & $\mathrm{C4}$ & $\mathrm{C5}$ \\
positif & 0.2664 & 0.15874 & 0.076 & 0.04134 & 0.01741 \\
negatif & 0.1998 & 0.11905 & 0.057 & 0.03101 & 0.01741 \\
\hline
\end{tabular}

\begin{tabular}{|llll|}
\hline Jarak Solusi \& Nalai Preferensi & & \\
\hline & Positif & Negatif & Preferensi \\
A1 & 0.0452 & 0.0666 & 0.59573 \\
A2 & 0.0452 & 0.0666 & 0.59573 \\
A3 & 0.01034 & 0.07982 & 0.88536 \\
A4 & 0.07753 & 0.02163 & 0.21813 \\
& & & \\
\hline
\end{tabular}

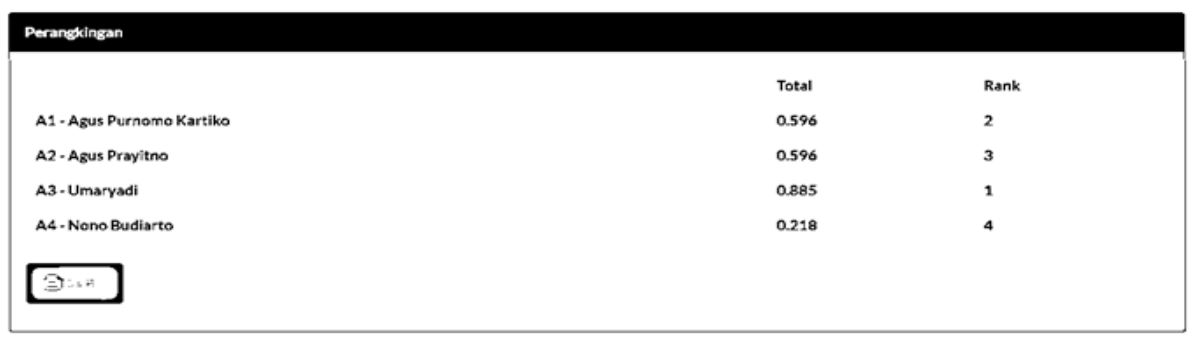




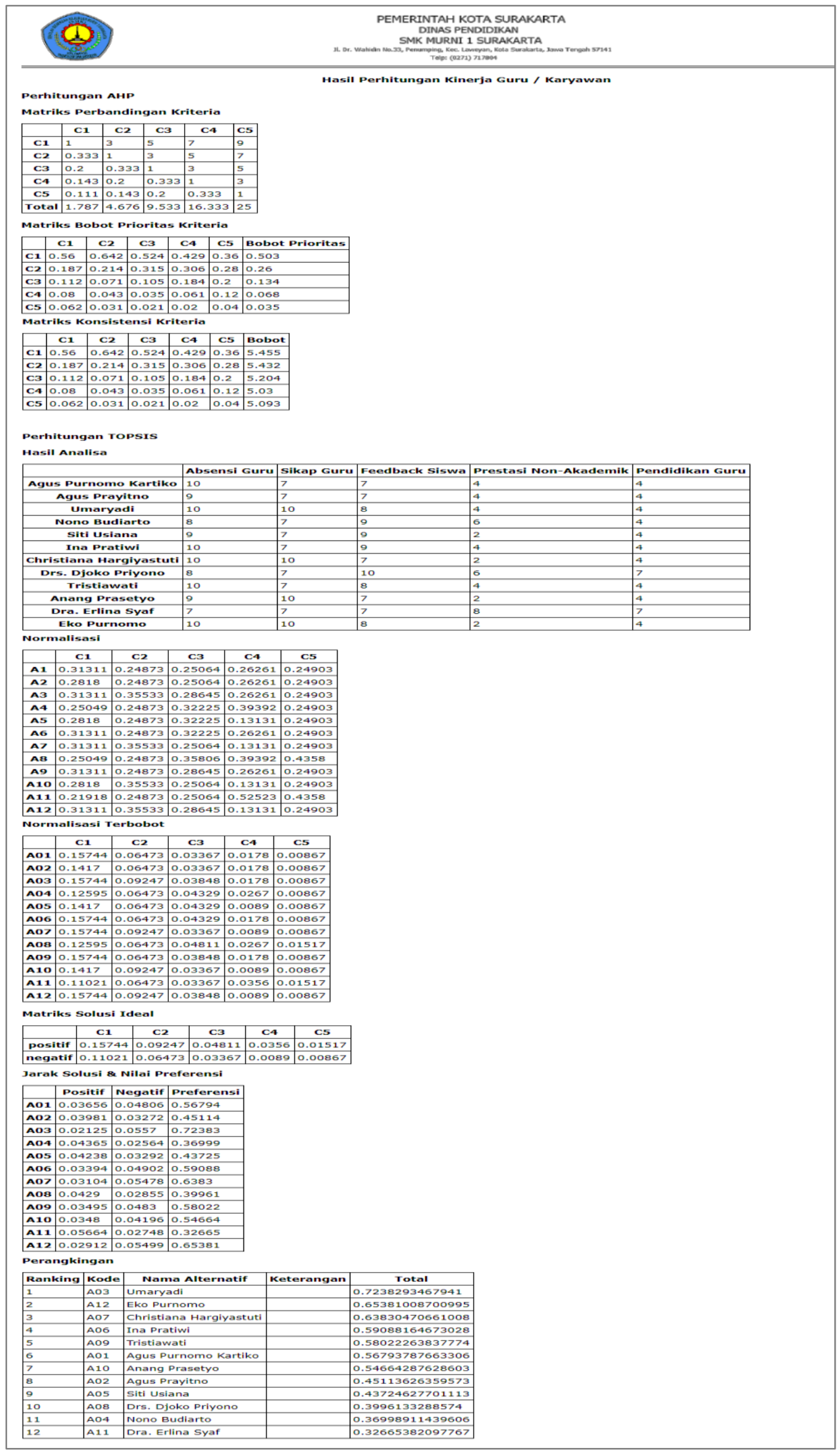

Gambar 5.Tampilan Hasil Perhitungan 


\subsection{Pengujian}

Pengujian dilakukan dengan pengujian validitas dilakukan terhadap sistem yang telah dibuat terhadap sistem yang sedang berjalan, perhitungan manual dan sistem komputerisasi yang telah dibuat.

Tabel 12 Hasil Pengujian Validitas

\begin{tabular}{|c|l|c|c|c|l|}
\hline No & Nama & $\begin{array}{c}\text { Sistem } \\
\text { Berjalan }\end{array}$ & $\begin{array}{c}\text { Manual } \\
\text { AHP- } \\
\text { TOPSIS }\end{array}$ & $\begin{array}{c}\text { Aplikasi } \\
\text { dengan } \\
\text { AHP- } \\
\text { TOPSIS }\end{array}$ & Ket. \\
\hline 1 & Guru 1 & 87,73 & 0.5679 & 0.5679 & Rank 6 \\
\hline 2 & Guru 2 & 87,67 & 0.4511 & 0.4511 & Rank 8 \\
\hline 3 & Guru 3 & 88,12 & $\mathbf{0 . 7 2 3 8}$ & $\mathbf{0 . 7 2 3 8}$ & Rank 1 \\
\hline 4 & Guru 4 & 87,33 & 0.3700 & 0.3700 & Rank 11 \\
\hline 5 & Guru 5 & 87,52 & 0.4372 & 0.4372 & Rank 9 \\
\hline 6 & Guru 6 & 87,83 & 0.5909 & 0.5909 & Rank 4 \\
\hline 7 & Guru 7 & 87,89 & 0.6383 & 0.6383 & Rank 3 \\
\hline 8 & Guru 8 & 87,46 & 0.3996 & 0.3996 & Rank 10 \\
\hline 9 & Guru 9 & 87,78 & 0.5802 & 0.5802 & Rank 5 \\
\hline 10 & Guru 10 & 87,72 & 0.5466 & 0.5466 & Rank 7 \\
\hline 11 & Guru 11 & 87,28 & 0.3267 & 0.3267 & Rank 12 \\
\hline 12 & Guru 12 & 87,93 & 0.6538 & 0.6538 & Rank 2 \\
\hline
\end{tabular}

Pada Tabel 12 dapat dilihat bahwa hasil dari pengujian terdapat perbedaan nilai pada sistem yang sedang berjalan dengan sistem aplikasi menggunakan metode AHP dan TOPSIS. Pada sistem berjalan hasil akhir untuk rekomendasi kenaikan jabatan diberikan kepada Guru 3 dengan nilai 88,12, sedangkan pada perhitungan dengan aplikasi diberikan kepada Guru 3 dengan nilai 0,7238. Hal ini dikarenakan proses perhitungan pada sistem yang dibangun selain memproses nilai yang didapat pada setiap alternatif, juga mempertimbangkan bobot yang ada disetiap kriteria.

\section{KESIMPULAN DAN SARAN}

\subsection{Kesimpulan}

1. Terbangunnya Aplikasi Sistem Pendukung Keputusan Kenaikan Jabatan bagi Guru dengan menggunakan metode $A H P$ dan TOPSIS yang memiliki fasilitas untuk input bobot dan kriteria, proses perhitungan untuk menentukan kenaikan jabatan dengan AHP dan TOPSIS yang hasilnya dapat di cetak.

2. Terdapat lima kriteria dalam penentuan kenaikan atau promosi jabatan SMK Surakarta, yaitu meliputi: Sikap (C1), Absensi (C2), Feedback Siswa (C3), Prestasi Non-Akademik (C4), dan Pendidikan Terakhir (C5). Masing-masing kriteria mempunyai atribut yang berupa Benefit dan Cost. Benefit yaitu jika nilai dari satu kriteria semakin banyak, maka semakin baik pula nilainya, sedangkan Cost yaitu jika nilai dari satu kriteria semakin sedikit, maka semakin baik pula nilainya. Dalam penelitian ini, seluruh penilaian kriteria memiliki atribut Benefit.

3. Hasil pengujian terdapat perbedaan nilai akhir yang diberikan untuk promosi kenaikan jabatan guru, yaitu pada sistem yang sedang berjalan diberikan kepada guru terbaik dengan nilai 88,12 , sedangkan hasil perhitungan dengan aplikasi ini yaitu dengan menggunakan metode $A H P$ dan TOPSIS diberikan kepada guru terbaik dengan nilai 0,7238 . 


\subsection{Saran}

Penggunaan metode lain seperti Simple Multi Attribute Rating Technique Method (SMART) atau ELECTRE untuk penentuan kenaikan jabatan guru, sebagai pembanding agar alternatif yang dihasilkan dapat lebih akurat.

\section{DAFTAR PUSTAKA}

Andriyani, N., \& Hafiz, A. (2018). Perbandingan Metode AHP dan Topsis dalam Penentuan Siswa Berprestasi. Seminar Nasional Teknologi Dan Bisnis 2018, 362-371.

Arbelia, \& Paryanta. (2014). Penerapan Metode AHP Dan TOPSIS Sebagai Sistem Pendukung Keputusan Dalam Menentukan Kenaikan Jabatan Bagi Karyawan. Jurnal Ilmiah Go Infotech, Vol. 20(1), Hal. 9-17.

Chamid, A. A., \& Murti, A. C. (2017). Kombinasi Metode AHP dan TOPSIS Pada Sistem Pendukung Keputusan. SNATIF, 115-119.

Herman Firdaus, I., Abdillah, G., \& Renaldi, F. (2016). Sistem Pendukung Keputusan Penentuan Karyawan Terbaik Menggunakan Metode AHP Dan TOPSIS. Seminar Nasional Teknologi Informasi Dan Komunikasi (SENTIKA), 440-445.

Latif, L. A., Jamil, M., \& Abbas, S. H. (2018). Sistem Pendukung Keputusan Teori Dan Implementasi. Deepublish.

Nanik Hidayati dkk. (2016). Sistem Pendukung Keputusan Metode AHP dan TOPSIS untuk Penentuan Staf Kurikulum Sekolah. Seminar Nasional Teknologi Informasi Dan Multimedia 2016, 6-7.

Nofriansyah, D., \& Defit, S. (2017). Multi Criteria Decision Making (MCDM) pada Sistem Pendukung Keputusan. Deepublish.

Ramayanti, G., \& Ulum, H. (2017). Sistem Penentuan Supplier Kawat Las Dengan Metode Analitycal Hierarchy Process (AHP) dan Technique for Order Preference by Similarity to Ideal Solution (TOPSIS). Jurnal Sistem Dan Manajemen Industri, Vol. 1(1), Hal. 1218. https://doi.org/10.30656/jsmi.v1i1.166

Riandari, F., Hasugian, P. M., \& Taufik, I. (2017). Sistem Pendukung Keputusan Menggunakan Metode TOPSIS Dalam Memilih Kepala Departemen Pada Kantor Balai Wilayah Sungai Sumatera II Medan. Journal Of Informatic Pelita Nusantara, Vol. 2(1), 6-13.

Saaty, T. L. (2004). Decision making — the Analytic Hierarchy and Network Processes (AHP/ANP). Journal of Systems Science and Systems Engineering, 13(1), 1-35. https://doi.org/10.1007/s11518-006-0151-5

Sari, D. R., Windarto, A. P., Hartama, D., \& Solikhun, S. (2018). Sistem Pendukung Keputusan untuk Rekomendasi Kelulusan Sidang Skripsi Menggunakan Metode AHPTOPSIS. Jurnal Teknologi Dan Sistem Komputer, Vol. 6(1), 1. https://doi.org/10.14710/jtsiskom.6.1.2018.1-6

Servanda, Y., \& Kusrini. (2018). Analisis Penentuan Prioritas Media Promosi Perguruan Menggunakan Kombinasi AHP dan TOPSIS. Metik Jurnal, 2(2), 1-9. 